\title{
TEMPERATURE REGULATION IN PARAPLEGIA
}

\author{
By R. H. Johnson, M.A., M.D., D.M., D.Phil. \\ University Department of Neurology, Institute of Neurological Sciences, Southern General \\ Hospital, Glasgow, S.W.I
}

\section{INTRODUCTION}

UNTIL the last decade disturbances of body temperature, other than pyrogenic fever, were little recognised and were described as medical curiosities. A report from the Royal College of Physicians (1966) highlighted the danger of hypothermia to a large number of people, particularly the elderly. Nevertheless the danger of disturbance of their temperature regulatory mechanisms to patients with traumatic transection of the spinal cord was first recognised nearly a century ago by Sir Jonathan Hutchinson (1875). Until after World War II these patients usually lived only a few weeks after injury and observations were therefore limited. Gardiner and Pembrey (1912), however, drew attention to the inability of paraplegics to maintain their central temperature when their environmental temperature was changed and indicated that they were virtually poikilothermic, thus: 'When the patient is exposed to moderate cold the temperature falls, and if the patient is exposed to a warm environment the temperature rises'.

These authors and Gordon Holmes (1915) pointed out that patients with cervical cord lesions, in particular, were often found to have subnormal temperatures and in Holmes' series the temperatures ranged from $80-90^{\circ} \mathrm{F} .\left(26 \cdot 7-32 \cdot 2^{\circ} \mathrm{C}\right.$.). Foerster (I936) found that some tetraplegics died of hyperthermia. Lefevre (I9II) divided hypothermia into two types: physiological hypothermia, in which patients responded to short periods of cold exposure by increasing their body temperatures, and pathological hypothermia, in which patients respond to cold exposure by a progressive fall in body temperature during and after cold exposure. Patients with high dorsal and cervical lesions cool rapidly on cold exposure: their hypothermia is pathological and due to an interruption of normal temperature regulatory mechanisms (Tigay, 1956; Guttmann, Silver \& Wyndham, 1958). As paraplegics have imperfect homeostasis and cannot maintain a normal central temperature if there is a great change in environmental temperature, it is important in their management to be aware of the danger to life of such temperature changes (Pledger, 1962). Hyperpyrexia and hypothermia do not occur to any great extent in paraplegics unless there is poor control of their ambient temperature and insulation by clothing, thus an extensive study of the progress of tetraplegics did not include faulty temperature regulation as a cause of their morbidity or mortality (Silver \& Gibbon, 1968).

The failure of normal temperature regulation occurs because of interference with both the mechanisms of heat production and of heat loss, upon the balance of which depends the body's thermal homeostasis. That temperature regulation is a homeostatic mechanism was pointed out by Claude Bernard in his observations on 'La fixité du milieu intérieur' (1878). The mechanisms by which human heat loss and production are regulated consist of two controlling systems. The first 
depends upon nervous reflexes from peripheral temperature receptors in the skin: the pathway of the reflex probably passes through the brain and its activity may be determined by the level of central temperature. The second depends upon receptors within the brain which respond to changes in blood temperature. The thermoregulatory activity of the central nervous system is not entirely determined by the central temperature and by afferent information from the periphery but also by the activity of pyrogens, which can alter the body's 'set point' of temperature so that fever develops. In addition heat loss from the skin may be affected by ambient temperature change and this effect is probably not dependent on neuronal activity.

\section{HEAT PRODUCTION}

Cold causes a rise in heat production in man via a rise in asynchronous muscular activity which later becomes synchronous and is obvious as shivering.

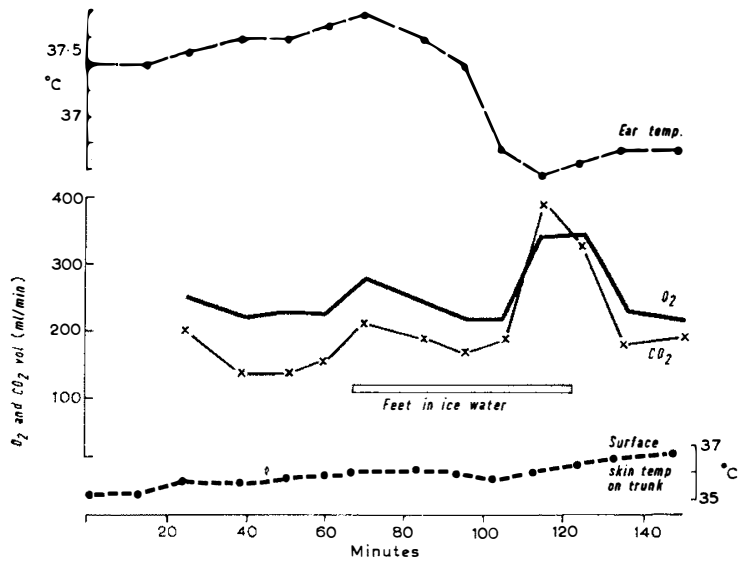

FIG. I

The effect of cooling the feet of a paraplegic (N.O., $\mathrm{T}_{7}$ transection) in ice-water $\left(4^{\circ} \mathrm{C}\right.$.). $\mathrm{O}_{2}$ consumption $(-)$ and $\mathrm{CO}_{2}$ output $(\mathrm{x}-\mathrm{x})$ rose after $40 \mathrm{~min}$. When the ear temperature (external auditory meatus, - ) fell to about $36 \cdot 7^{\circ} \mathrm{C}$. there was obvious shivering which ceased when the ear temperature rose to $36 \cdot 8^{\circ} \mathrm{C}$. There was little change in superficial temperature on the trunk (- - - ). (Gas volumes are expressed at s.t.p.) (From Johnson \& Spalding, 1966, by kind permission.)

Although small mammals have non-shivering thermogenesis in viscera (Davis \& Meyer, 1955) and it is also possible in infants, via mobilisation of brown fat as a result of sympathetic activity (Hull, I966), there is evidence against its occurrence in adult man (Johnson \& Spalding, I963; Johnson, Smith \& Spalding, 1963). Shivering usually occurs in spite of a rise in central temperature in adult man and therefore appears to depend on a reflex from cold skin.

In paraplegics shivering does not occur in muscles innervated from below the level of the lesion and the shivering reflex does not therefore appear to be a spinal one. The failure of the trunk and limb shivering in patients with high cervical cord transection indicates that the reflex ascends above the level of their lesion and probably through the brain: patients with paraplegia therefore have only a limited contribution to their thermoregulation from reflex shivering initiated 


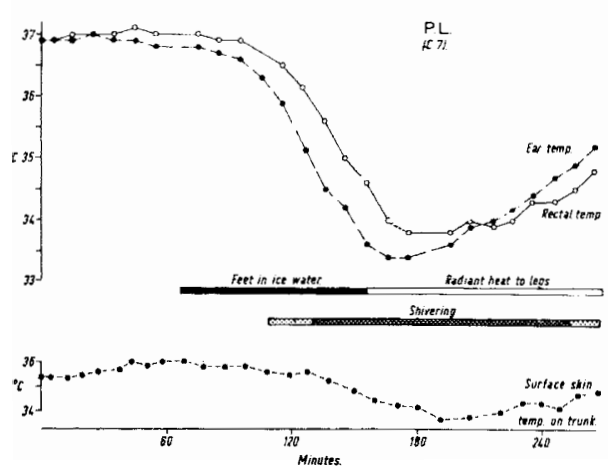

A

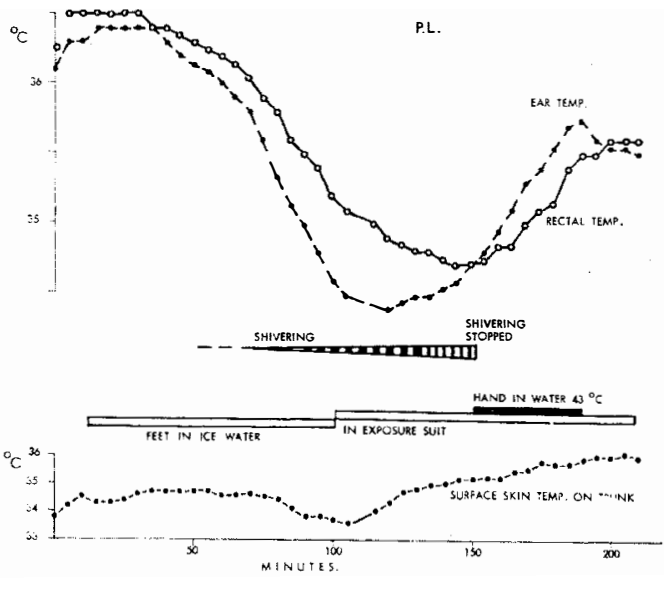

B

FIG. 2

(A) The effect on subject P. L. (C7 transection) of cooling the feet in ice-water and subsequently warming them by radiant heat. Changes in ear temperature (external auditory meatus, --0$)$ and rectal temperature $(\mathrm{O}-\mathrm{O})$. Shivering, indicated by the horizontal bar, occurred when the central temperature fell below $36 \cdot 5^{\circ} \mathrm{C}$. even though the skin above the level of the lesion was warm (- - - ). (Johnson \& Spalding, 1966, by kind permission.) (B) A similar investigation to that shown in (A) in the same patient (P. L.). On this occasion, however, a hand with normal sensory innervation was placed in warm water at $43^{\circ} \mathrm{C}$. as indicated. Even though the central temperature was only $34.7^{\circ} \mathrm{C}$., shivering was inhibited abruptly.

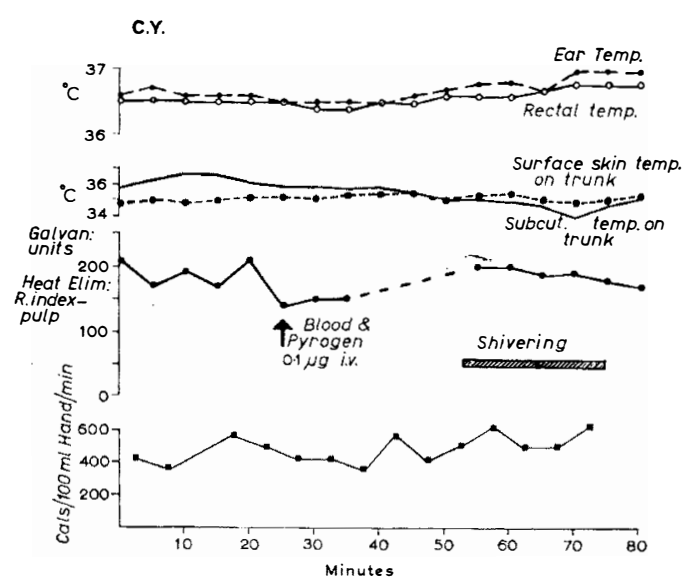

FIG. 3

The effect of blood pyrogen incubate ( $0 \cdot \mathrm{I} \mu \mathrm{g}$. Pyrexal), given intravenously to a patient (C. Y.) with complete traumatic transection of the cervical cord (C6-7). Shivering was observed in muscles innervated from above the lesion. At the same time no evidence of skin vasoconstriction was obtained when studied in the fingers by calorimetry (Greenfield \& Scarborough, I949 - ), and by heat flow discs (Hatfield, I950; arbitrary galvanometer units, ). (From Johnson, 1966, by kind permission.) 
by cold receptor activity above the level of their lesion. The increase in metabolism achieved by paraplegics during cold exposure depends upon the amount of muscle which is still normally innervated. It has been shown that in some subjects with cervical cord transection cold exposure causes a rise in metabolism of 50 per cent. above their resting level (Guttmann, Silver \& Wyndham, 1958) but none of our patients with high lesions responded to cooling to this extent (Johnson \& Spalding, 1966).

There has been controversy about whether or not shivering may also be caused by a fall in central temperature (Hemingway, 1963) and studies in association with cord transection have indicated that shivering may be evoked in this way. The initial evidence depended on animal investigations. Sherrington (I924) cooled the hind legs of dogs with complete transection of the spinal cord and observed shivering in muscles innervated from above the level of the lesion. Evidence from similar investigations in paraplegic patients (figs. I, $2 \mathrm{~A}$ ) indicate that similar activity can be evoked in man even though skin with a normal sensory innervation is warm (Johnson \& Spalding, I964b, 1966; Downey, Miller \& Darling, 1969). Shivering occurred in muscles innervated above the lesion when the ear (external auditory meatus) temperature fell below $36 \cdot 2^{\circ} \mathrm{C}$. The fall in central temperature was not associated with a conscious appreciation of cold and one patient (T8 transection) observed 'I don't know whether I am shivering or whether I've got an attack of nerves' (Johnson, I965a). Although the shivering can be initiated by a fall in central temperature the centre is very sensitive to afferent information and shivering can be inhibited abruptly by warming normally innervated skin (fig. 2, B). This is analagous to the situation in which sweating may be inhibited by sudden application of cold to a limb even though the central temperature remains high.

Heat production not only increases in response to cold but also occurs in infections and results in fever. Studies of a patient with cervical cord transection showed that after receiving pyrogen shivering occurred only in normally innervated muscle and therefore the pyrogen probably acts centrally above the level of his lesion (C6). There was also absence of vasoconstriction, which normally occurs in intact subjects and this also supports the view that the pyrogen acts above the C6 level and not directly on blood vessels (Bryce-Smith, Coles, Cooper Cranston \& Goodale, 1959) or on nerve cells in the spinal cord or their connections (fig. 3). Our subject did not have headache during the investigation, suggesting that the headache which is normally experienced in pyrogen induced fever does not result from a direct action of pyrogen on intracranial structures and may depend on sympathetic activity (Cooper, Johnson \& Spalding, I964b).

\section{HEAT LOSS}

The most important forms of heat loss regulation in man depend upon cutaneous vasomotor activity and sweating, apart, of course, from conscious regulation by putting clothes on or taking them off and by altering the temperature of the environment. Conscious control depends upon the appreciation of cutaneous temperature only and not upon appreciation of a change in central temperature. Other means of varying heat loss are panting and piloerection. Panting is important in other mammals and may also occur in paraplegics with high lesions, and is not dependent on autonomic nervous system activity. It produces increased 
evaporation from the upper respiratory airways and, because of the shallowness of the respiration, there is minimal alveolar ventilation and little disturbance of arterial $\mathrm{pCO}_{2}$. Piloerection, which increases insulation, is only vestigial in man and depends upon sympathetic nervous activity. It may result from hypothalamic stimulation (Walker, I940) or from a spinal reflex from cold skin (Thomas, I92I) and it is therefore observed in paraplegics below the level of their lesion.

The efferent autonomic nerve fibres which subserve sweating and vasomotion appear to pass as distinct fibre tracts in the medulla and spinal cord (Prout, Coote \& Downman, 1965) and it is therefore possible for irregular trauma to the cord, or a local cord lesion of other cause, to produce dissociation of vasomotor function from sweating activity. It is therefore not possible to conclude that complete autonomic denervation has occurred after observing whether or not only one of these functions is still active (Johnson \& Prout, I966).

Thermoregulatory vasomotor activity and sweating are both dependent upon the dual control of a reflex and of a central temperature receptor mechanism. Reflex vasodilatation, usually observed in the hand, requires large areas of skin to be warmed and it may occur within $15 \mathrm{sec}$. of the onset of radiant heating. Further evidence for its occurrence is that vasodilatation may develop during radiant heating of the trunk with a concomitant fall in central temperature and also that when the legs are heated, vasodilatation in the hand occurs, even though the blood flow to and from the legs is occluded (Kerslake \& Cooper, I950; Cooper \& Kerslake, I954).

Although some autonomic reflexes may be mediated by a spinal reflex, for example the pilomotor response already discussed, the gasp reflex (Gilliatt, Guttmann \& Whitteridge, I947), the cold pressor response (Pollock, Boshes, Chor, Finkelman, Arieff \& Brown, 195I) and vasomotor and sudomotor responses to bladder stimuli (Guttmann \& Whitteridge, 1947), it appears that reflex vasodilatation is not spinal. Thus warming or cooling patients with cervical cord transection in whom these reflexes were active did not cause any change in hand blood flow (fig. 4) and therefore the reflex must be dependent on nervous pathways above the C6-7 level of the spinal cord (Johnson \& Spalding, 1964a). Appenzeller and Schnieden (1963) working at the same time made similar observations. We also checked skin and central temperatures as skin temperature should be above $32^{\circ} \mathrm{C}$. and central temperature above $36 \cdot 5^{\circ} \mathrm{C}$. for the reflex to be active (Cooper, Johnson \& Spalding, I964a, c; Johnson, I965a,b). These observations do not support Foerster's suggestion (I936) that the spinal cord may exhibit 'spinal centre activity' and react to change of temperature in the same way as the hypothalamus.

Thermal sweating also depends upon structures above the spinal cord even though sweating may be evoked by changes in vesical and bowel pressure in patients with spinal cord section. Thermoregulatory sweating is therefore absent in areas which are autonomically denervated by the cord transection. Thus patients with cervical cord transection do not sweat at all in response to heat and those with lower lesions only sweat above a level which is about four segments below the level of their somatic lesion. This is because autonomic dermatomes overlap several segments above and below the somatic level. The presence of sweating in an anaesthetic area may have contributed to observations suggesting the presence of spinal reflex sweating (Seckendorf \& Randall, 1958; Boshes \& Blostein, 1960). There is occasionally a band of excessive sweating at this level, known as 'border zone' sweating, which may be due to irritation or partial interruption of fibres near the region of trauma. 


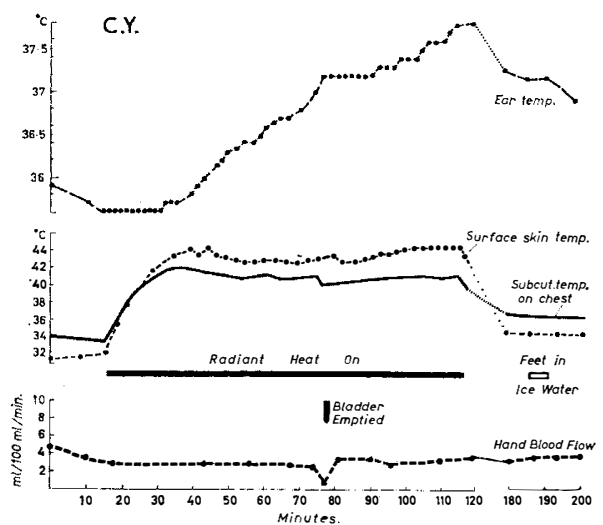

A
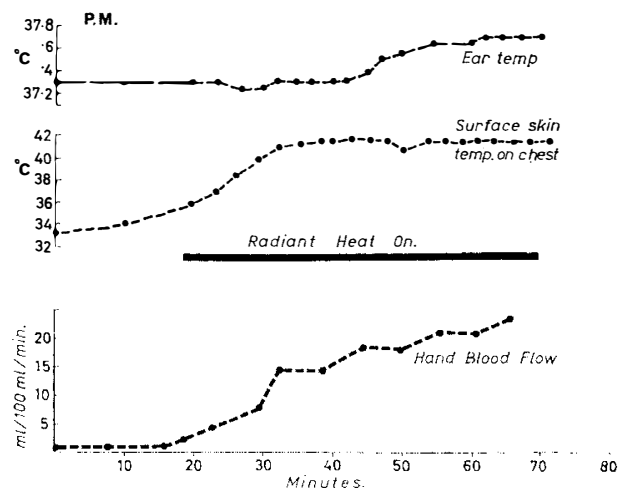

Fig. 4

B

(A) Absence of changes in hand blood flow (- - - - 0) in subject C. Y. (complete C6-7 transection) with considerable elevation in skin temperature and ear temperature (external auditory meatus, - - - ) by the application of radiant heat to the trunk. (From Johnson, I965a, by kind permission.) (B) A similar investigation in a normal subject, P. M., for comparison.

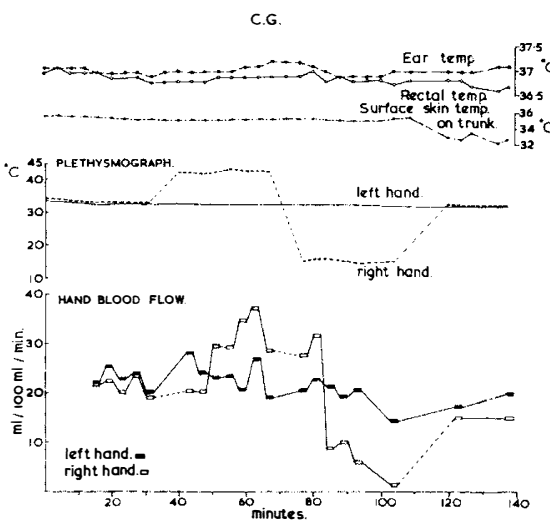

A
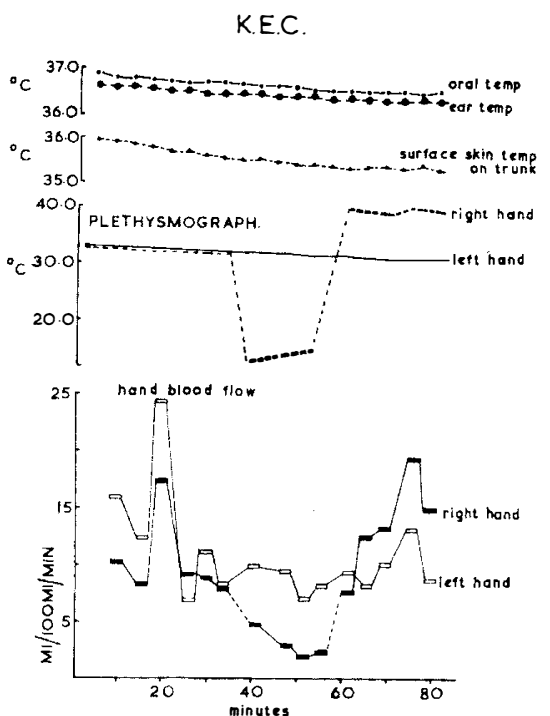

FIG. 5

B

(A) Observations on left and right hand blood flow (each point averages Io flows) in subject C. G. (complete $\mathbf{C} 8$ transection) when the left plethysmograph temperature was kept constant at about $32^{\circ} \mathrm{C}$. while the right plethysmograph temperature was changed as indicated. (From Johnson, 1965a, by kind permission.) (B) A similar investigation in a normal subject, K. E. C., for comparison.

The Local Effect of Ambient Temperature. Besides blood vessels being controlled by the activity of neurones activated by a centre in the brain, it has been shown that blood vessels will constrict or dilate according to the local effect 
of the surrounding temperature. This has been observed in sympathectomised limbs (Freeman, I935) and could be one of the mechanisms by which a subject with a cervical cord lesion controls his temperature. We carried out investigations upon three subjects with cervical cord transection in whom both hands were put in plethysmographs and the temperature of one was altered while that of the other was kept constant. Vasoconstriction occurred when the hand was cooled and vasodilatation when the hand was warmed (fig. 5). This response indicates the possible importance of the effect of local temperature on skin blood vessels as a further mechanism by which a paraplegic's temperature may be partially controlled.

This paper has described physiological observations made possible by cord transection because it produces dissociation of function of different parts of the nervous system and allows separate study of them. Such are the differences between man and animals, for example hair and sweat gland distribution, that our understanding of human temperature depends upon such observations. The physiologist interested in temperature regulation can echo the philosophical message of Alexander Pope ${ }^{1}$ :

'Know then thyself ...

The proper study of mankind is man'

(An Essay on Man: Book 2.)

\section{SUMMARY}

Patients with transection of the spinal cord run the risk of hypothermia or hyperpyrexia. They have lost the ability to shiver below the somatic level of their lesion. Heat loss mechanisms are also interrupted, the loss being complete below the autonomic dermatome level affected. Piloerection can occur below the level of the lesion; some vasoconstriction and vasodilatation can also occur below the level of the lesion in response to change in ambient temperature. Studies of paraplegics have allowed a greater understanding of human temperature regulation.

\section{RÉSUMÉ}

Les malades avec une transection de la moëlle épinière peuvent courir le risque d'une hypothermie ou d'une hyperthermie. Ils ont perdu, en effet, la possibilité du frisson audessous de leur lésion. Les mécanismes de déperdition calorique sont aussi interrompus, cette perte étant complète au-dessous du dermatome autonome. Une piloérection peut survenir au-dessous du niveau de la lésion. Une vasoconstriction et une vasodilatation partielles peuvent aussi survenir au-dessous du niveau de cette lésion en réponse au changement de température ambiante. L'étude effectuée sur les paraplégiques a permis une meilleure compréhension de la régulation thermique chez l'homme.

\section{ZUSAMMENFASSUNG}

Patienten mit Transektion des Rückenmarks sind der Gefahr von Hypothermie oder Hyperpyrexie ausgesetzt. Sie haben die Fähigkeit verloren, unterhalb der Läsion zu frösteln. Piloerection und etwas Vasokonstriktion sowie Vasodilatation kann unterhalb der Läsion auftreten als Reaktion von Veränderungen der umgebenden Temperatur. Studien an Paraplegikern haben zu einem besseren Verständnis der menschlichen Temperaturregulation geführt. 
Acknowledgments. This paper depends upon observations carried out upon autonomic nervous system activity while working in Oxford and Glasgow: I wish to thank the patients for their helpful cooperation; Professor W. Ritchie Russell, Dr. J. M. K. Spalding, Dr. K. E. Cooper, Sir George Pickering, and Professor J. A. Simpson have provided much encouragement. I also wish to thank the National Fund for Research into Poliomyelitis and other Crippling Diseases, the British Medical Association, and the Medical Research Council, for support.

\section{REFERENCES}

APPENZElleR, O. \& SCHNieden, H. (1963). Neurogenic pathways concerned in reflex vasodilatation in the hand with especial reference to stimuli affecting the efferent pathway. Clinical Science, 25, 4I3-42 I.

BERNARD, ClAUde (1878). Leçons sur les phenomenes de la vie. Paris: Baillière.

Boshes, B. \& Blostein, H. (I960). Survival of sympathetic nervous system after spinal cord injury and measured by the sweat mechanism. Archives of Neurology, 2, 163-I7I.

Bryce-Smith, R., Coles, D. R., Cooper, K. E., Cranston, W. I. \& Goodale, F. (I959). The effects of intravenous pyrogen upon the radiant heat induced vasodilatation in man. Fournal of Physiology, 145, 77-84.

CoOper, K. E. \& KerslaKe, D. MCK. (I954). Some aspects of the reflex control of the cutaneous circulation. Ciba Symposium 'Peripheral Circulation in Man', pp. I43-I49. Churchill: London.

Cooper, K. E., Johnson, R. H. \& Spalding, J. M. K. (I964a). The effect of cutaneous temperature of the trunk on reflex vasodilatation in the hand. Fournal of Physiology, I70, 50-5I P.

CoopeR, K. E., Johnson, R. H. \& SPALding, J. M. K. (I964b). Thermoregulatory reactions following intravenous pyrogen in a subject with complete transection of the cervical cord. Fournal of Physiology, 171, 55-56 P.

Cooper, K. E., Johnson, R. H. \& SPALDING, J. M. K. (I964c). The effects of central body and trunk temperature on reflex vasodilatation of the hand. Fournal of Physiology, I74, $46-54$.

Davis, T. R. A. \& MEYeR, J. (I955). Demonstration and quantitative determination of the contributions of physical and chemical thermogenesis on acute exposure to cold. American fournal of Physiology, I8I, 675-678.

Downey, J. A., Miller, J. M. \& Darling, R. C. (I969). Thermoregulatory responses to deep and superficial cooling in spinal man. Fournal of Applied Physiology, 27, 207-212.

FoERSTER, O. (1936). Bumke and Foerster's Handbuch für. Neurologie. Berlin: Springer.

FREEMAN, N. E. (1935). The effect of temperature on the rate of blood flow in the normal and the sympathectomized hand. American fournal of Physiology, 113, 384-398.

GARDINER, H. \& PEMBREY, M. S. (I9I2). Observations on the temperature of man after traumatic sections of the spinal cord. Guy's Hospital Reports, 46, 86-108.

Gilliatt, R. W., GutTMANN, L. \& WhitTERIDGE, D. (1947). Inspiratory vasoconstriction in patients after spinal injuries. Fournal of Physiology, 107, 67-75.

GreEnField, A. D. M. \& SCARborough, H. (I949). An improved calorimeter for the hand. Clinical Science, 8, 2 I I-2I5.

GuttmanN, L., Silver, J. \& Wyndham, C. H. (1958). Thermoregulation in spinal man. fournal of Physiology, 142, 406-419.

GutTMANN, L. \& WhITTERIDGE, D. (I947). Effects of bladder distension on automatic mechanisms after spinal cord injuries. Brain, 70, 361-404.

Hatrield, H. S. (1950). A heat flow meter. Fournal of Physiology, III, Io P.

Hemingway, A. (1963). Shivering. Physiology Reviews, 43, 397-422.

Holmes, G. (I915). Spinal Injuries of Warfare. British Medical fournal, 2, 769-774; 8 I 5-2I; 855-6I.

Hull, D. (1966). The structure and function of brown adipose tissue. British Medical Bulletin, 22, 92-96.

Hutchinson, J. (I875). Temperature and circulation after crushing of the cervical spinal cord. Lancet $i$, 713-715. 
Johnson, R. H. (1965a). Neurological studies in temperature regulation. Annals of the Royal College of Surgeons, England, 36, 339-352.

Johnson, R. H. (1965b). Some vasomotor changes in temperature regulation in man. Bibliotheca anatomica, 7, 288-293.

Johnson, R. H. (1966). The autonomic nervous system and body temperature. Proceedings of the Royal Society of Medicine, 59, 463-466.

Johnson, R. H. \& Prout, B. J. (I966). Dissociation of some sympathetic nervous functions. Bibliotheca Anatomica, 9, 349-354.

Johnson, R. H., SMith, A. C. \& SPALding, J. M. K. (1963). Oxygen uptake of paralysed man exposed to cold. Fournal of Physiology, 169, 584-591.

Johnson, R. H. \& Spalding, J. M. K. (I963). Whole body metabolism of a paralysed man during surface cooling. Fournal of Physiology, 166, 24-25 P.

Johnson, R. H. \& Spalding, J. M. K. (I964a). The effect of surface and central temperature on hand blood flow in subjects with complete transection of the cervical cord. fournal of Physiology, 171, I4-15 P.

Johnson, R. H. \& SPALDING, J. M. K. (I964b). Shivering and central temperature. fournal of Physiology, 173, 34-35 P.

Johnson, R. H. \& SPALDING, J. M. K. (I966). The role of a central temperature receptor in shivering in man. Fournal of Physiology, 184, 733-740.

Kerslake, D. MCK. \& CoOper, K. E. (I950). Vasodilatation in the hand in response to heating the skin elsewhere. Clinical Science, 9, 31-47.

Lefèvre, J. (I9I I). Chaleur animale et Bioénergétique. Paris: Masson et Cie.

PLEDGER, H. G. (I962). Disorders of temperature regulation in acute traumatic tetraplegia. Fournal of Bone and foint Surgery, 44B, I IO-I I 3 .

Pollock, L. J., Boshes, B., Chor, H., Finkelman, I., AriefF, A. J. \& Brown, M. (I95I). Defects in regulatory mechanisms of autonomic function in injuries to the spinal cord. Fournal of Neurophysiology, 14, 85-93.

Prout, B. J., Coote, J. H. \& Downman, C. B. B. (I965). Independence of central controls of vascular and sweat gland responses in the paw of the cat. Fournal of Neurology Neurosurgery and Psychiatry, 28, 223-227.

Royal College of Physicians, London (1966). Report of committee on accidental hypothermia.

SECKENDORF, R. C. \& RANDALl, W. C. (1958). Thermal reflex sweating in paraplegic man. Federation Proceedings, 17, I44.

SHERRINGTON, C. S. (1924). Notes on temperature after spinal transection with some observations on shivering. Fournal of Physiology, 58, 405-423.

Silver, J. R. \& Gibbon, N. O. K. (1968). Prognosis in Tetraplegia. British Medical Fournal, 2, 79-83.

Thomas, A. (I92I). Le Reflex Pilomoteur. Paris: Masson et Cie.

TigAY, E. L. (I956). Dysregulation of temperature control in cervical cord lesions. Proceedings of I5th Annual Clinical Paraplegia Conference, Veterans Administration Hospital, Illinois, 80-85.

Walker, E. A. (I940). The hypothalamus and pilomotor regulation. Proceedings of Association for Research in Nervous and Mental Diseases, 20, 400. 